(C) 2021 Katedra Białorutenistyki UW. Wydanie w otwartym dostępie na licencji CC BY-NC-ND (https://creativecommons.org/licenses/by-nc-nd/4.0/deed.pl)

ACTA ALBARUTHENICA 21: 2021

DOI: 10.32612/uw.18988091.2021.21.pp.53-69

\title{
Мікола Хаўстовіч/ Mikałaj Chaustowicz
}

Uniwersytet Warszawski / University of Warsaw ORCID: https://orcid.org/0000-0002-3007-0603

e-mail: m.khaustovich@uw.edu.pl

\section{Забельскі рукапісны зборнік: праблемы атрыбуцыі і тэксталогіi}

The Zabelsky Manuscript Collection: Problems of Attribution and Textology

Zabialski zbiór rękopisów - problemy atrybucji i tekstologii

\section{Пад шыфрам: LMAVB, f. 18, b. 201}

Пасля скасавання расейскаю адміністрацыяй Забельскага кляштара тамтэйшыя кніжніца ды архіў трапілі спачатку да полацкіх дамініканцаў, а ў 1867 г. сталіся набыткам Віленскае публічнае бібліятэкі. У 1903 г. з матэрыяламі забельскіх дамініканцаў (прынамсі, з рукапісным зборнікам, у якім знаходзіўся шэраг літаратурных твораў) пазнаёміўся прафесар Кіеўскага ўніверсітета Уладзімір Ператц (1870-1935) [Отчетъ... 1904: 28]. У друку пра гэты зборнік ўпершыню згадала Антаніна Сычэўская ў 1909 г. у артыкуле Къ вопросу о Мольерп въ польской драматической литературп XVIII cm. [Сычевская 1909: 75109] ва "учено-педагогическомъ журналь” "Русскій филологический вЂстникъ”. Праўда, згадка А. Сычэўскае адно інфарматыўная: “Хранится она [п'еса Doktór przymuszony. - M. X.] въ рукописномъ сборникъ Виленской публичной библіотеки въ листъ № 201. Составленъ этотъ сборникъ ксендзомъ Морашевскимъ - профессоромъ піитики и ксендзомъ Цецерскимъ - профессоромъ реторики" [Сычевская 1909: 77].

Яўхім Карскі (1861-1931), у той час рэктар Варшаўскага ўніверсітэта (1905-1910), магчыма, з часопіса, які сам рэдагаваў, даведаўся пра існаванне “польско-бълорусской обработки кс. Цецерскаго”, пазнаёміўся і вывучыў зборнік № 201 ды падрыхтаваў публікацыю Камедыі [Карскій 1912: 314]. Аднак славуты беларускі твор упершыню быў надрукаваны ў 1911 г. у даследаванні У. Ператца [Перетц 1911: 248319]. Навуковец коратка апісаў і ахарактарызаваў зборнік, звярнуў увагу, што гэта “остатки литературы на бълорусскомъ языкъ, сохра- 
нившіеся кое-гдъ по старымъ школьнымъ тетрадямъ іезуитскихъ школъ" [Перетц 1911: 274]. Я. Карскі і беларускія даследнікі ўнеслі шэраг істотных правак у расчытаны У. Ператцам тэкст Камедыі. Але, на нашую думку, сёння патрэбна як новае апісанне зборніка, так і новае расчытанне Камедыі. Напачатку мы пералічым усе тэксты, якія ўвайшлі ў склад зборніка [LMAVB-18-201: 13v-29].

\begin{tabular}{|c|c|}
\hline Стар. & Тытул \\
\hline 1 & $\begin{array}{l}\text { Continuatio operis Scholastici Patris Caietani Moraszewski Profes- } \\
\text { soris Rhetorices et Poeseos In Gimnasijs Zabialiensis Anno D-ni 1787, } \\
\text { Dec. } 24\end{array}$ \\
\hline $1 \mathrm{v}-13$ & Tragedya Wolność w Niewoli \\
\hline $13 v-29$ & Komedya \\
\hline 30 & $\begin{array}{l}\text { Collectanea. M M: O D. Rhetarum et Poetarum in unum collecta per me } \\
\text { Fratrem Michaelem Ciecierski Professorem Rhetorices in Con[ven]tu } \\
\text { Zabialiensi Ordinis Praedicatorum. A. } 1787\end{array}$ \\
\hline $31-31 v$ & $\begin{array}{l}\text { Mowa J: W: J: Xdza Margrafa Achety ArcyBiskupa Chalcedonskiego, Nuncyu- } \\
\text { sza stolicy Apostolskiejy przy Krolu y Rzeczy Pospolitey Polskiey rezydującego } \\
\text { miana w Charakterze Posła od Tey że stolicy u Dworu Petersburskiego na D. } \\
15 \text { Julii N: S. } 1783 \text {. Roku z Francuskiego na Ruskie, z Ruskiego na Polskie } \\
\text { tłomaczona a dla pamiątki tu wpisana }\end{array}$ \\
\hline $31 \mathrm{v}$ & $\begin{array}{l}\text { Odpowiedź Nayiasnieyszey Katarzyny drugiey Imperatorowey Rossyskiey etc } \\
\text { etc etc. }\end{array}$ \\
\hline 32 & $\begin{array}{l}\text { Oracya Winszująca Prefekta Rożancowego miana w Dzien Niepokalanego } \\
\text { Poczęcia N: P: Maryi }\end{array}$ \\
\hline $32 v$ & Oda z Tey że samey Materyi \\
\hline 33 & $\begin{array}{l}\text { Oratio Gratulatoria A. R. P. S. T. Mgro Casimiro Wieszczycki Priori Conventus } \\
\text { Zabialensis in Die Nominalium dieta }\end{array}$ \\
\hline $33-35$ & Oratio In Laudem Divi Thome Agrunatis \\
\hline $35-42$ & $\begin{array}{l}\text { Poręka Przyiacielska czyli Sprawa Sądowa w Dzien So Tomasza z Aquinu Z: K: } \\
\text { w Roku } 1788 \text { marca } 7 \text { D. }\end{array}$ \\
\hline $42 \mathrm{v}$ & Concordia res parve crescund, discordia et maximie dilabuntur \\
\hline 43 & $\begin{array}{l}\text { Mowa. Nauczyciel do Uczniow mowi odwodzqc ich odwzaiemney między sobq } \\
\text { nienawiści }\end{array}$ \\
\hline $43 \mathrm{v}$ & Mowa Do Judasza, który Pana Chrystusa na smierć Żydom wydał \\
\hline $44 \mathrm{v}$ & $\begin{array}{l}\text { Oratio Gratulatoria Nominalium RP Jacobi Wyszowaty Proffessoris Grama- } \\
\text { tices et syntaxeas in Cntis Zabialensi OP }\end{array}$ \\
\hline $45-49 v$ & $\begin{array}{l}\text { Elegia de Passione Christi continens Misteria Rosarij: Modlitwa Jezusa w Og- } \\
\text { roycu. Biczowanie Jezusa. Koronowanie Jezusa. Krzyża niesienie na Górę } \\
\text { Kalwaryskq. Krzyżowanie }\end{array}$ \\
\hline $50-74 \mathrm{v}$ & Sapor: Tragedya w piąciu aktach \\
\hline $75-96$ & Doktor Przymuszony: Komedya w piąciu aktach \\
\hline
\end{tabular}

Знаёмства з тэкстамі, уключанымі ў Зборнік, дазваляе мець пэўнае меркаванне пра час ягонага ўзнікнення. Як сведчыць тытульная старонка першае яго часткі, 24 снежня 1787 г. першы перапісвальнік рас- 
пачаў працу1․ Цягам некалькіх наступных дзён два перапісвальнікі занатавалі ў зборнік драматургічныя творы, аўтарам якіх лічыцца К. Марашэўскі. Потым перапісвальнік № 1 пачаў другую частку (на тытульнай старонцы пазначаны 1787 г.), праца над якою працягвалася даволі доўга. Калі, напрыклад, прамовы нунцыя Джавані Архэці (17311805) і Кацярыны II (1729-1796), датаваныя 1783 г., маглі быць перапісаныя яшчэ ў тым жа 1787 ці пачатку 1788 г., дык шэраг "рытарычных практыкаванняў”, занатаваных на старонках 32-49, з'явіліся тут значна пазней: школьны дыялог Poręka Przyiacielska czyli Sprawa Sq̨dowa w Dzien So Tomasza z Aquinu, падрыхтаваны студэнтамі Мікалаем Косавым, Стафанам Шчаткоўскім, Юзафам Кішкаю, Матэвушам Ліпскім, Феліцыянам Даўловічам, Каролем Косавым, узнік блізу 1 сакавіка 1788 г., a Oratio Gratulatoria ў гонар новага прыёра Забельскага кляштара Казіміра Вяшчынскага/Вяшчыцкага і Oratio Gratulatoria Nominalium у гонар прафесара граматыкі і сінтаксісу Якуба Вышаватага маглі быць напісаныя (першая - студэнтам Мікалаем Косавым), хіба, у верасні 1788 г., калі пасля чарговае капітулы новыя асобы занялі пасады ў канвенце. Выходзіць, трагедыя Canap і камедыя Доктар па прымусу, “сабраныя” ці напісаныя М. Цяцерскім “з'явіліся” ў Зборніку яшчэ пазней.

Далей у полі нашага зроку будзе толькі першая частка Зборніка, г. зн. два драматургічныя творы, напісаныя - як лічыць большасць даследнікаў - К. Марашэўскім. Вельмі сумнеўна, што мы маем справу 3 аўтарскім аўтографам. Як ужо гаварылася, над першаю часткаю зборніка працавалі трое: нехта, можа, больш дасканалы ў каліграфіі, аформіў тытульную лацінамоўную старонку, літары якое маюць па-барочнаму квяцістае аздабленне. Тэксты ж твораў перапісвалі двое: большую частку працы выканаў перапісвальнік № 2 (старонкі 1v-23v) - 45 старонак з 56. Перапісвальнік № 3 пачаў з 16 (апошняе) сцэны II акту Камедыі і занатаваў цалкам III акт - усяго 11 старонак (старонкі 23v 29). Перапісвальнікамі, магчыма, былі студэнты "studium" (клерыкі) ці браты з кляштару. Абодва перапісвальнікі не вылучаліся дасканаласцю пры запісе як польскага, так і беларускага тэкстаў. Выявілася гэта ў:

а) злітным напісанні слоў з прыназоўнікамі, злучнікамі, часціцамі і інш.

б) адвольным напісанні дыякрытычных знакаў ( $\boldsymbol{s}$ замест $\boldsymbol{s}, \boldsymbol{z}$ замест $\dot{\boldsymbol{z}}, \boldsymbol{c}$ замест $\boldsymbol{c}$, а таксама $\boldsymbol{l}$ замест $\boldsymbol{\ell}$ і інш.).

в) адвольным напісанні вялікае і малое літары.

\footnotetext{
${ }^{1}$ Існуе і іншае меркаванне: “а затым ідзе час напісання ці, верагодна, заканчэння твора, бо значыцца не толькі год - 1787, але і больш дакладная дата - 24 снежня" [Усікаў 1964: 130].
} 
г) адвольнаю пастаноўкаю знакаў прыпынку; невылучэнне сказаў, што часта ператварае тэкст у складаны для разумення перыяд; адсутнасцю парцэляцыі тэксту.

Дадзеныя, на нашую думку, “недахопы”, тлумачацца тым, што перапісвальнікі працавалі паспешліва і пад дыктоўку. Апошняе можна яскрава праілюстраваць, параўноўваючы запісы першага і другога перапісвальнікаў беларускага тэксту Камедыі. Гэта заўважыў яшчэ У. Ператц:

Пьеса написана двумя почерками (второй - съ 16 сц. II д.) и въ зависимости отъ этого въ рьчи Мужика (Chłopa) наблюдаются колебанія: въ 1-мъ - sie, nie, Djabet, ciepier, już, Paniczenko и т. д., во 2-мъ - sia, nia, Djabat, ciapier, juz, Paniczańku (vocat.) и т. д. [Перетцъ 1911: 278].

"Колебаній”, ці то дыялектных адрозненняў быць не магло, каб перапісвальнікі мелі перад вачыма, скажам, аўтограф ці аўтарскую копію. Відаць, успрымаючы тэкст на слых, яны на пісьме адлюстроўвалі асаблівасці беларускае гаворкі таго рэгіёну, адкуль самі паходзілі. Як варыянт: чытальнікі маглі “папраўляць" аўтарскае напісанне - зноў жа - у адпаведнасці з беларускім вымаўленнем свайго рэгіёну.

Мы не ведаем, як было насамрэч. Але ў выніку "забельскіх маніпуляцый" атрымалі Камедыю, беларускія часткі якое (сc. $13 \mathrm{v}-23 \mathrm{v}$ i 23v-29) маюць розныя фанетычныя і марфалагічныя асаблівасці. Такога быць не магло, каб перапісванне “кантраляваў” сам аўтар. Відавочна, аўтар не ўдзельнічаў у гэтым працэсе: пацвярджэннем сказанаму можа быць і адсутнасць у трагедыі Wolność w Niewoli - пры захаванні чыстага месца - перад III актам Intermedium 3 (с. 10). Прычым, перапісвальнік пакінуў месца прыкладна на тры шасцірадковыя страфы (столькі ж месца займалі інтэрмедыі перад I і II актамі). Як і калі трагедыю павінны былі дапоўніць Intermedium 3? I чаму яна не была дапоўненая, калі аўтар знаходзіўся ў кляштары, а Зборнік цягам доўгага часу дапісваўся? I ці магла трагедыя ставіцца на сцэне, калі адсутнічала ейная істотная інтэгральная частка?

\section{Забельскі дамініканскі кляштар}

Віцебшчына, тэрыторыя якое ўваходзіла ў склад г. зв. Літоўскае правінцыі прапаведнікаў св. Анёла Ахоўніка (Ordo Fratrum Praedicatorum), што была ўтвораная ў 1647 г. на генеральнай капітуле ў Валенсіі (тут і далей выкарыстоўваем звесткі з кнігі [Wołyniak 1917: 1-48, 284317]). У той час у правінцыі мелася толькі 12 канвентаў / кляштараў. Праз стагоддзе іх было ўжо блізу пяцідзесяці.

Забельскі кляштар, заснаваны ў 1716 г., цягам нейкіх 15-20 гадоў набыў вялікую значнасць у ордэне, дзякуючы сваім фундатарам - 
Юрыю і Ганне з Гласкаў Шчытам-Забельскім, якія пасля смерці адзінага сына Аляксандра запісалі ўвесь свой маёнтак дамініканцам, што служылі ў іхняй капліцы ў Забелах, дзеля будаўніцтва касцёла і кляштара ў мястэчку Валынцы. Спачатку была ўзведзеная драўляная святыня, а ў 1750-я гг. - мураваная (архітэктар Іаган Крыштаф Глаўбіц).

Валыняк [Jan Marek Giżycki] даволі дэталёва апісаў гісторыю забельскіх дамініканцаў на падставе рукапіснае Хронікі канвента. Але цікава, што яшчэ ў XIX ст. па-энцыклапедычнаму лаканічна фактычна тое самае пісаў у Геаграфічным слоўніку Адам Красцэнты Лапацінскі (1826 - да 1897) у артыкулах пра Забелы і Валынцы. Магчыма, і ён, абывацель Дзісеншчыны (прынамсі, ягоная маці паходзіла з блізкага ад Валынцаў фальварка Друйка) ды сталы аўтар Слоўніка, быў знаёмы з Хронікаю, складзенаю забельскімі манахамі.

Варта яшчэ дадаць колькі інфармацый пра Забельскі кляштар тае эпохі, калі ў ім жыў і працаваў К. Марашэўскі. Перш-наперш пра назву кляштара. На нашую думку, даволі пераканаўча гэта зрабіў Валыняк:

Будаваць касцёл і кляштар пачалі ў Валынцах, бо яны былі ўласнасцю дамініканцаў ужо з першага запісу, і там сапраўды паўстала святыня і канвент, але з тае прычыны, што першы касцёл (ці капліца) быў у Забелах, дык гэтая назва стала так агульнапрызнанаю і агульнапрынятаю, што яе перанеслі і на пазнейшую сядзібу законнікаў у Валынцах, хоць, праўду кажучы, адно ад другога вельмі блізка, а неўзабаве і Валынцы, і Забелы належалі дамініканцам ды сталіся адным цэлым [Wołyniak 1917: 293].

Дададзім яшчэ толькі: фундатарамі былі Забельскія, а г. зн., што кляштар насіў імя не толькі геаграфічнае назвы фальварка (двара), але адначасна і ягоных заснавальнікаў-ахвярадаўцаў ${ }^{1}$.

У часы прыёрства айца Аўрэлі Любавіцкага (1759-1761) пры кляштары пачала працаваць аптэка, жыў тут лекар-немец, а пасля хірург, лекі (у тым ліку - каву) прывозілі пераважна з Рыгі. Пад 1764 годам упершыню ў Хроніцы ідзе гаворка пра “бакаляра”, які выкладаў у школцы, што існавала, хіба, і раней; таксама згадваецца "kurs retoryki zakonnej", які выкладае а. Чэслаў Фільніс.

3 канца 1760-х гг. у кляштары стала неспакойна: расейскія войскі чынілі шмат клопатаў манахам, а калі ў 1772 г. Полаччыну імперыя акупавала, дык узніклі праблемы з камунікаваннем паміж канвентамі Літоўскае правінцыі дамініканцаў: на тэрыторыі іншай дзяржавы апынулася сем кляштараў (Рушона, Посін, Аглона, Полацк, Орша, Княжыцы,

${ }^{1}$ Вядома, што нашчадкі Вінцэнта, роднага брата Юрыя, а таксама сваякі Ганны Гласкі шматразова дамагаліся аспрэчыць і ў судзе, і з дапамогаю наездаў запісаны дамініканцам маёнтак. Называючы кляштар “Забельскім", манахі ўшаноўвалі волю фундатараў і пацвярджалі сваё права на валоданне. 
Забелы). 3 гэтай прычыны, пэўна, неўзабаве і ўзнікла Беларуская правінцыя дамініканцаў (існавала да часу поўнае акупацыі беларускіх зямель).

На жаль, палітычныя перамены адбіліся і на характары запісаў у Хроніцы: Валыняк адно называе прыёраў: Аляксандар Шыстоўскі (1769-1773), Канты Багінскі (1773-1774), Вінцэнты Даўнаровіч (17741775), Яцак Струміла (1775-1776), Альберт Шалуха (1776-1783), Міхал Казлоўскі (1783-1786), Чэслаў Папроцкі (1786-1788), Казімір Вяшчынскі (1788-1791).

Маем надзею, што пошукі ў дамініканскіх архівах некалі дадуць магчымасць адказаць на пытанне: ці існаваў пры Забельскім дамініканскім кляштары калегіум - навучальная ўстанова для дзяцей заможнае шляхты, накшталт Полацкага езуіцкага калегіума, які знаходзіўся ў сарака вёрстах ад Валынцаў?

\section{Калегіум і тэатар у Валынцах}

Як мы ўжо згадвалі, пра навучальныя ўстановы ў Валынцах пэўных звестак пакуль не выяўлена. Дарэчы, устаноў такіх павінна было быць некалькі: апрача школкі для шляхецкіх, мяшчанскіх і сялянскіх дзяцей, дзе працаваў “бакаляр", яшчэ да адкрыцця навіцыяту ў Забельскім кляштары ў 1738 г. быў створаны "studium filozoficzny" [Fibek, online], а г. зн., што на гэты курс маглі запісацца асобы, якія ўжо закончылі "ніжэйшыя" курсы - відавочна, у езуіцкіх калегіумах - "граматыкі", "сінтаксісу”, “паэтыкі" і "рыторыкі". Неўзабаве ў Валынцах з'явіўся i "studium teologiczny" [Wołyniak 1917: 301], што дазволіла казаць пра "studium formalne" ў кляштары. Валыняк згадвае, што ў 1764 г. забельскія студэнты мелі і курс рыторыкі. У 1769 г. упершыню ў кляштары адбылася ардынацыя pro sacrim ordinibus - шэраг клерыкаў атрымаў пасвячэнні. Гэта сведчыць, што да першага падзелу Рэчы Паспалітае ў Валынцах паспяхова працавала навучальная ўстанова. Праўда, як гэта было прынятае ў манаскіх ордэнах, называлася яна адно "studium" (курс).

Адзначым яшчэ, што ў 1772 г. у кляштары жыло 57 манахаў (18 святароў, 22 клерыкі-семінарысты, 11 братоў, 6 навіцыяў-паслушнікаў). Канвікту (інтэрнату), здаецца, не было. Прынамсі, Валыняк не згадвае пра гэта, хоць падобнае з прычыны значных фінансавых выдаткаў павінна было адлюстравацца ў Хроніцы. Азначае гэта, што ў 1772 г. у кляштары навучаліся толькі клерыкі і навіцыі, колькасць якіх ніколі не перавышала трыццаці.

Як паўплывала новая палітычная сітуацыя пасля 1772 г. на працэс навучання ў Валынцах і на колькасць навучэнцаў-студэнтаў, - мы не ведаем. Аднак пэўна тое, што ў сярэдзіне 1780 -х гг. у тутэйшай навучальнай установе існаваў - як мінімум - “курс паэтыкі” і “курс рыто- 
рыкі". Пра гэта сведчыць рукапісны зборнік, у якім пазначана, што ў 1787 г. у кляштары жыў і працаваў прафесар рыторыкі і паэтыкі К. Марашэўскі і прафесар рыторыкі М. Цяцерскі.

Варта больш уважліва прыгледзецца тым запісам. Зборнік адкрываецца тытульнаю старонкаю раздзела К. Марашэўскага:

Continuatio | operis | Scholastici | Patris Caietani | Moraszewski | Professoris | Rhetorices et Poeseos | In Gimnasijs Zabialiensis | Anno D-ni 1787, Dec. 24|.

У перакладзе:

Працяг рытарычных практыкаванняў айца Каятана Марашэўскага, прафесара рыторыкі і паэтыкі ў Забельскай гімназіi. У год Гасподні 1787, 24 снежня ${ }^{1}$.

На тытульнай старонцы раздзела М. Цяцерскага, чытаем:

Collecta|nea. | M M: O D. | Rhetarum et Poeta|rum in unum collecta per me Fratrem Michaelem Ciecier|ski Professorem Rhe|torices in Con[ven]tu Zabialiensi Ordinis Praedicatorum. A. 1787.

У перакладзе:

Калекцыя. MM: OD. Рытарычныя і паэтычныя практыкаванні сабраныя мною, братам Міхалам Цяцерскім, прафесарам рыторыкі ў Забельскім канвенце Ордэна прапаведнікаў. 1787 год.

Абодва гэтыя тытулы выканала адна асоба, але ў адным выпадку навучальная ўстанова названая “гімназія”, а ў другім гаворка ідзе пра прафесара канвенту². Характэрна, што ў першым выпадку уужываецца не лацінскае "kolegium" (школа з бурсаю, канвіктам), а грэцка-лацінскае "gimnasium" (школа практыкаванняў).

Усё гэта можа быць сведчаннем, што, па-першае, у Забельскім дамініканскім кляштары ўтрыманне навучальнае ўстановы дыктавалася неабходнасцю падрыхтоўкі святароў. Нагадаем: асноўная мэта ордэну дамініканцаў - прапаведніцтва і місіянерская дзейнасць. Вось чаму столькі ўвагі надавалася курсу рыторыкі (у невялікім кляштары працавалі адначасна два прафесары!). Па-другое, у дамініканскай вучэльні адукацыю набывала невялікая колькасць студэнтаў.

У сувязі з гэтым варта задаць пытанне: а ці існаваў пры Забельскім дамініканскім кляштары тэатар? Беларускія даследнікі адназначна казалі, што п'есы, прынамсі, Камедыя з рукапіснага зборніка была “напісаная і пастаўленая ў Забельскай калегіi ў 1787 годзе” [Мальдзіс 1974: 152]. Гэта значыць, што ў мястэчку Валынцы пры Забельскім дамініканскім кляштары была калегія / калегіум, у якой ладзіліся пас-

\footnotetext{
${ }^{1}$ Існуюць іншыя варыянты перакладу тытула раздзела. Пра гэта гл. ніжэй.

2 Дапускаем, што перапісвальнік дакладна перадаваў зыходны рукапіс.
} 
таноўкі, г. зн. працаваў тэатар. Аднак ці ёсць якія пісьмовыя крыніцы, якія сведчаць пра існаванне калегіума і тэатра? На жаль, такія крыніцы пакуль не выяўленыя. Можна меркаваць, што калегіум і тэатар “узніклі” на пачатку XX стагоддзя па аналогіi з навучальнай і тэатральнай дзейнасцю езуітаў. Так, з аднаго боку мы бачым створаныя па ўсіх правілах драматургічнага майстэрства п'есы, якія паходзяць з Забельскага кляштара, але з другога - не маем аніякіх пацвярджэнняў, што гэтыя творы ставіліся ў Забельскім дамініканскім кляштары. Цікава, аднак, тое што ўсе тэксты ў зборніку падаюцца як "рытарычныя практыкаванні”. Ці не азначае гэта, што яны прызначаліся проста дзеля чытання, дзеля заняткаў?

Не можам мы не звярнуць увагу і на тое, што дамініканцы Літоўскае і Беларускае правінцый не ладзілі, здаецца, публічных тэатральных пастановак. Прынамсі, адзін з першых даследнікаў тэатральнага руху на Літве і Беларусі Юліян Ціціус (1820-1898) не называе братоў-прапаведнікаў сярод тых (езуітаў, базыльянаў, піяраў), хто выкарыстоўваў дзеля сваіх мэтаў падобнае [Titius 1840: 179-182 і інш.]. А ён вельмі добра ведаў полацка-дрысенскі рэгіён. Чаго варта, напрыклад, ягонае апісанне тэатра Алаіза Буйніцкага ў мястэчку Забор'е (на тракце з Глыбокага ў Дзісну) [Samborska-Kukuć 2003: 3-4].

Ю. Ціціус, дарэчы, шмат увагі прысвяціў г. зв. школьным дыялогам -тэатральным пастаноўкам езуітаў. Няўжо пра калегіум і навучальны працэс дамініканцаў ў Валынцах ён проста нічога не ведаў?

Нашае дапушчэнне, што пры Забельскім дамініканскім кляштары не было калегіума і тэатра, небясспрэчнае. Але ці павінны сёння адваротныя аксіаматычныя сцверджанні лічыцца верагоднымі? Так, даследніца рэлігійнага жыцця ў Беларусі XVIII-XIX стст. Раiса Зянюк піша:

Пры школе працаваў тэатр, дзе ажыццяўляліся пастаноўкі, аўтарамі якіх былі выкладчыкі калегіўма. Тэатральныя пастаноўкі выкарыстоўваліся як форма і метад навучання [Зянюк 2012: 355].

I не спасылаецца, на жаль, на крыніцы. Тут, пэўна, паўплывалі на навукоўца шматлікія публікацыі даволі аўтарытэтных гісторыкаў літаратуры. На нашую думку, самым важкім аргументам на карысць існавання калегіума і тэатра ў Валынцах было даследаванне Адама Мальдзіса. Апавядаючы пра твор з Практыкаванняў (1789-1791) М. Цяцерскага Апалон-заканадаўща, або Зрэфармаваны Парнас, аперэтка, якая складаецца з дыялогаў $і$ спеваў, ён пераказвае прадмову. 3 пераказу вынікае, што аперэтка "напісана <...> для спектакля з поваду заканчэння школьнага года" [Мальдзіс 1974: 170]. Здаецца, усё зразумела: раз сам аўтар называе практычную мэту свае працы, дык аніякіх сумненняў быць не можа: аперэтка прызначалася для спектакля ў Забельскім 
кляштары. Аднак насцярожвае той факт, што зборнік 1787 г. называўся Рытарычныя і паэтычныя практыкаванні, сабраныя мною, братам Міхалам Цяцерскім ... Звяртаем увагу на слова “сабраныя". Ці не павінна яно схіліць нас засумнявацца ў аўтарстве М. Цяцерскага тэкстаў, уключаных у гэты зборнік? I дыялогі, і драматургічныя творы могуць паходзіць з розных дамініканскіх ды недамініканскіх асяродкаў былое Рэчы Паспалітае, а таксама Заходняй Еўропы (пераклады - у апошнім выпадку - маглі быць выкананы і ў Забельскім кляштары). Не мае тут значэння і тое, што ў Камедыі з пяці актаў А. Мальдзіс заўважыў “лакальны каларыт": падзеі ў ёй адбываюцца "паблізу ад Валынцаў, на берагах Дрысы” [Мальдзіс 1974: 168]. Бо перапісвальнік мог дазволіць сабе ўнесці змены.

Выказваючы меркаванне, што пра Забельскім дамініканскім кляштары хутчэй за ўсё не было калегіума, мы аніяк не змяншаем ягоную ролю як значнага культурна-асветнага цэнтра Паўночнае Беларусі ў XVIII - пачатку XIX стагоддзя. На нашую думку, у Валынцах “дзейнічаў” своеасаблівы асяродак па падрыхтоўцы і перапісванні “практыкаванняў” дзеля навучання студэнтаў-клерыкаў як у “слаўных Забелах", так і ў іншых дамініканскіх кляштарах. Пра гэта сведчыць захаваная рукапісная спадчына літоўска-беларускіх дамініканцаў. Уважліва аналізуючы забельскі рукапіс 1787 г., мы прыйшлі да высновы, што ён не можа з'яўляцца ні аўтографам К. Марашэўскага, ні аўтографам М. Цяцерскага. Гэта зборнік, які ўзнік у кляштарным скрыпторыі. Тэксты драматургічных і інш. твораў запісваліся пад дыктоўку. А гэта азначае, што адначасна паўставала некалькі зборнікаў. На шчасце, адзін 3 ix захаваўся.

\section{Праблема аўтарства Камедыі}

У. Ператц, не маючы звестак ні пра самога К. Марашэўскага, ні пра ягоную творчасць, напачатку відаць, сумняваўся, што Камедыя належыць пяру прафесара рыторыкі і паэтыкі:

Изъ этого заглавія можно заключить, что передъ нами лишь часть обширнаго собранія драматическихъ произведеній собранныхъ, а м о жетъ быть - ин написанныхъ о. Морашевскимъ (вылучэнне нашае.- M.X.), ибо обычно встарину сочиненіе пьесъ лежало на обязанности преподавателей реторики и піитики, обязанныхъ не только наставлять учениковъ въ теоріи, но и на практикъ давать имъ образцы, достойные подражанія [Перетцъ 1911: 275].

Праўда, крыху ніжэй ён нібыта ўжо пазбываецца сваіх сумненняў:

Знакомясь ближе съ пьесами оо. Морашевскаго и Цецерскаго, убђждаемся въ томъ, что это - опыты старинной школьной драмы, но со сльдами 
вліянія новаго классицизма, при томъ скоръе итальянскаго, чьмъ французскаго [Перенцъ 1911: 277].

Прыкладна такое ж стаўленне да праблемы аўтарства беларускапольскіх камедый Зборніка... і ў Я. Карскага: у адпаведнасці з тытуламі частак ён піша, што рукапіс "складзены” К. Марашэўскім і М. Цяцерскім [Карскій 1921: 228], але пазней гаворыць пра іх, як пра аўтараў: “БЪлорусская рђчь у Цецерскаго вышла хуже, нежели у Морашевскаго” [Карскій 1921: 232].

А вось Максім Гарэцкі ў Хрыстаматыі... [Гарэцкі 1922: 70-73], Выпісах... [Гарэцкі, Дзяржынскі, Каравай 1926: 284-297], а таксама у чацвёртым выданні Гісторыі... [Гарэцкі 1926: 98-99] ужо адназначна называе К. Марашэўскага аўтарам Камедыі, што - трэба сказаць - і замацавала дамініканца ў статусе беларускага літаратара. Праўда, адразу пасля выхаду ў свет Хрыстаматыі Адам Саладух (Уладзіслаў Талочка, 1887-1942) асцярожна запярэчыў М. Гарэцкаму:

Дамініканец Maraszewski (sic) у Забелах, аўтар беларускай камедыі, хіба, ідэнтычны а. Піліпу Макрэцкаму, які там у той час (1787 г.) быў і працаваў (у кніжцы пададзенае сапсаванае ${ }^{1}$ прозвішча) [Sołoduch 1923: nr 7]

Невядома, на падставе чаго А. Саладух прыпісвае Камедыю П. Макрэцкаму. Але, магчыма, падчас навучання ў Віленскай духоўнай каталіцкай семінарыі (1906-1909) ён пазнаёміўся з архівам Забельскага дамініканскага кляштару, бо якраз тады выйшаў у свет пяты выпуск Описанія Рукописнаго отдпленія Виленской публичной библіотеки (1906), дзе ішла гаворка пра рукапісы Забельскае бібліятэкі. Ды, відаць, звярнуў увагу і на Камедыю, і на спісы манахаў канвенту. Вось толькі ці не памыліўся А.Саладух, пішучы гадоў праз пятнаццаць водгук на Хрыстаматыю...?

Насамрэч у Забельскім кляштары жыў і працаваў дамініканец кс. Піліп Макрэцкі, але было гэта ў 1845-1858 гг., а не ў 1787 г. Цяжка паверыць у тое, што праз 58 гадоў пасля бытнасці ў Валынцах аднаго П. Макрэцкага з'явіўся ягоны аднаіменнік. Хутчэй, А. Салагуб проста “атаясаміў” аўтара Камедыі з адным з самых славутых дамініканцаў Літоўскае правінцыі XIX стагоддзя.

Здавалася б, можна было і не надаваць значэння сказанаму між іншым, фактычна адным словам у водгуку на Хрыстаматыю..., аднак у 1980-я гг. інфармацыю А. Саладуха “пацвердзіў” Георгій Колас (19291994), які працаваў тады “над разгадкай таямніц Камедыі Каятана Марашэўскага":

${ }^{1}$ у пазнейшых Bыnicax М. Гарэцкі не адмовіўся ад ранейшае атрыбуцыі Камедыі, але прозвішча аўтара падаў як Морашэўскі. 
Мая гіпотэза нічым не горшая за тую, што ўвайшла (бяздоказна) у навуковы ўжытак пра Каятана Марашэўскага: у штотыднёвіку „Przegląd Wileński” (№ 7, 1923) А. Саладух надрукаваў “здагадку”, што Камедыю стварыў не К. Марашэўскі, а Піліп Макрэцкі. А. Мальдзіс гэтую “здагадку” Саладуха не абмінуў, і нават адказаў яму, на першы погляд, вельмі слушна: "Прозвішча Марашэўскага выразна абазначана на вокладцы”. А Саладух, напэўна, мог бы запярэчыць Мальдзісу, што ён таксама бачыў (тут і далей вылучэнні Г. Коласа. - M.X.) тую “вокладку" (ці больш дакладна - першую старонку ў рукапісным сшытку), але Саладух, напэўна недзе бачыў, акрамя таго, яшчэ і тагачасны спіс настаўнікаў Забельскае калегіі (я сам яго таксама бачыў): Каятана Марашэўскага няма ў тым спісе, а Піліп Макрэцкі - ёсць [Колас 1988: № 1].

А. Саладух нічога не кажа пра "спіс настаўнікаў Забельскае калегіi". А вось пра які "спіс" вядзе гаворку Г. Колас? Пра "спіс" прафесараў "studium formalne" у кляштары? Дык у Валынцах, дзе на "studium" наведвалася дваццаць ці крыху больш студэнтаў-клерыкаў, і колькасць прафесараў была нязначнаю - на нашую думку, тры-чатыры асобы. Фармат літаратурна-публіцыстычнага выдання не патрабаваў ад даследніка спасылацца на крыніцу інфармацыі, а таму мы не можам спраўдзіць, што гэта за "спіс" і за якія гады бачыў Г. Колас, але запіс у Liber encyclicarum адназначна сведчыць, што ў 1788 г. К. Марашэўскі пакінуў Забельскі канвент і накіраваўся ў Аглону [Брыль 2018: 3]. Гэта значыць, у Валынцах ён дакладна жыў і працаваў.

Больш складана адказаць на пытанне: занатаванае ў раздзеле (с. 129) - гэта ўласныя творы К. Марашэўскага ці проста тэксты, якія ён падрыхтаваў (сабраў, склаў, перапрацаваў і інш.) дзеля заняткаў са студэнтамі на лекцыях паэтыкі альбо рыторыкі? Варта яшчэ раз прыгадаць тытульную старонку раздзела:

Continuatio | operis | Scholastici | Patris Caietani | Moraszewski | Professoris | Rhetorices et Poeseos | In Gimnasijs Zabialiensis | Anno D-ni 1787, Dec. 24|.

Першым з беларускіх даследнікаў варыянт перакладу тытулу прапанаваў на пачатку 1960-х гг. Якуб Усікаў:

Працяг твораў рытара айца Каэтана Марашэўскага, прафесара рыторыкі і паэзіі Забяльскай гімназіі [Усікаў 1964: 130].

Крыху пазней А. Мальдзіс нязначна паправіў пераклад:

Працяг твораў айца Каятана Марашэўскага, прафесара рыторыкі і паэтыкі Забельскай гімназіі [Мальдзіс 1974: 163].

Самае складанае і найважнейшае для нас у гэтым лацінамоўным тытуле - выраз "operis Scholastici". Ці маем мы права перакладаць яго як “творы”? Вольнасць у няволі і Камедыя сталі творамі для нас y XX стагоддзі. Для К. Марашэўскага ў першую чаргу - гэта працы дзеля 
школьных рытарычных практыкаванняў, школьных дыспутаў. Гэта школьныя працы, у якія выяўляецца схаластычная канцэпцыя тагачаснае навукі і адукацыі, спалучэнне тэалагічнае дагматыкі з рацыяналістычнай логікай Арыстоцеля.

Усё тое, што ёсць у гэтым зборніку і што было ў зборніку, які не захаваўся 1 , - выкарыстоўвалася К. Марашэўскім, але не ягоная ўласнасць у ягоным разуменні. Бо ж невыпадкова кожны тэкст завяршаецца формулай, якая прыкладна аднолькавая ледзь не ва ўсіх тагачасных школьных матэрыялах: $A d$ M[aiorem]: $D$ [ei]: $G I[$ oria]m - Дзеля большае славы Божае.

На наш погляд, ёсць падставы сумнявацца ў тым, што Камедыя належыць пяру К. Марашэўскага. Прынамсі, пакуль не выяўлена дакументаў, якія б пацвярджалі аўтарства прафесара паэтыкі і рыторыкі Забельскага канвенту. Аднак, прааналізаваўшы вытокі і крыніцы Камедыi, мы мяркуем, што К. Марашэўскі мог на падставе даступных яму матэрыялаў езуіцкага школьнага тэатра падрыхтаваць тэкст у адпаведнасці з тагачаснымі паэтыкамі і ўзорнымі "школьнымі камедыямі" Францішка Багамольца.

Нейкіх іншых паважных атрыбуцыйных гіпотэзаў адносна Камедыі мы пакуль не маем.

\section{Пра Каятана Марашэўскага}

Цягам ста гадоў гісторыкі літаратуры ведалі пра Каятана Марашэўскага толькі тое, што было пазначанае ў рукапісе, выяўленым у Віленскай публічнай бібліятэцы на пачатку XX стагоддзя У. Ператцам, А. Сычэўскай і Я. Карскім: у сярэдзіне 1780-х гг. беларускі драматург з'яўляўся прафесарам рыторыкі і паэтыкі “Забельскага дамініканскага калегіума" [Мальдзіс 1996: 390-391].

I толькі ў апошні час Антон Францішак Брыль выявіў шэраг дакументаў, якія дазваляюць дадаць некалькі істотных штрыхоў у біяграфію К. Марашэўскага [Брыль 2018: 3-4]. Па-першае, перад пачаткам 1788/1789 навучальнага года (г. зн. у жніўні 1788 г.) яго, відавочна, перавялі з Валынцаў у дамініканскі кляштар у Аглоне на пасаду выкладчыка (прафесара) у тамтэйшым "studium formalne". Па-другое, паводле спісу манахаў, у 1810 г. яму прыкладна 55 гадоў², і ён прыёр дамініканскага кляштара ў Шумску. Па-трэцяе, у 1811 г. К. Марашэўскі памёр.

Гэта значыць, цяпер мы ведаем гады ягонага жыцця: К. Марашэўскі нарадзіўся прыкладна ў 1755 г., а памёр у 1811 г. I што ён амаль усё

\footnotetext{
${ }^{1}$ Маем на ўвазе страчаны сшытак, у якім былі іншыя “operis Scholastici” К. Mapaшэўскага.

2 Вусная інфармацыя А.Ф. Брыля. Спіс манахаў 1810 г. ім яшчэ неапублікаваны.
} 
жыццё служыў дамініканскаму ордэну, стаўшы на схіле дзён нават прыёрам невялічкага кляштара. Вельмі верагодна, што К. Марашэўскі з дзяцінства быў звязаны з дамініканскім ордэнам, хоць не выключаем, што ён мог вучыцца ў адным з езуіцкіх калегіумаў.

Як ужо паведамлялася, у 1788 г. К. Марашэўскі быў накіраваны ў Аглонскі дамініканскі кляштар, што знаходзіўся ў Інфлянтах, латышскай частцы Полацкага намесніцтва (блізу 100 км на паўночны захад ад Валынцаў), на пасаду прафесара тамтэйшага "studium formalne". Сярод публікацый пра Аглонскі кляштар цікавым падаецца артыкул Дамініка Ходзькі (блізу 1800 - 1863) Аглона: Касцёл і кляштар аа. дамініканцаў [Chodźko 1856: 163], у якім шмат звестак пра мінулае святыні; аднак постаць К. Марашэўскага, відаць, не была так значнай, каб захавацца ў аналах гісторыі. Не згадвае пра яго ў Аглоне і Валыняк, бо “аглонскіх дамініканцаў мы ведаем толькі ад першае чвэрці XIX стагоддзя з Elenchusów zakonnych" [Wołyniak 1917: 56].

Пра жыццё і працу К. Марашэўскага з восені 1788 г. па 1810 г. звесткі пакуль не выяўленыя. За гэты час адбылося сем капітулаў Беларускае, а пасля “аб’яднанае" Літоўскае правінцый, і на кожнай з іх К. Марашэўскі мог атрымаць новае прызначэнне. Гэта значыць, да 1796 г. ён мог жыць не толькі ў Аглоне, але і ў адным з кляштараў Беларускае правінцыі: Рушоне, Посіне, Полацку, Оршы, Княжыцах і Валынцах. Пасля трэцяга падзелу Рэчы Паспалітае да вышэй згаданых дамініканскіх асяродкаў дадаліся блізу сарака іншых, што ўваходзілі ў склад узноўленае Літоўскае правінцыі. Але “след” К. Марашэўскага, зусім нядаўна адшуканы А.Ф. Брылём, захаваўся толькі ў мястэчку Шумск (сёння: Šumskas, Літва, на самай мяжы з Беларуссю): у 1810 г. ён быў (магчыма, толькі атрымаў прызначэнне) на чале тамтэйшага кляштара. Праўда, у Directorium... Літоўскае правінцыі дамініканцаў за 1812 г. пазначана, што прыёр Шумскага кляштара памёр у 1811 г. Аднак, здаецца, не ў Шумску, бо яго няма ў “пахавальных метрыках" Шумскага касцёла св. Міхала Арханёла.

У Шумску на пачатку XIX ст. ужо быў мураваны касцёл, а вось кляштар - адно драўляны. Валыняк у сваёй публікацыі пра Шумскі кляштар не згадвае К. Марашэўскага, хоць шмат увагі прысвячае ягонаму наступніку Віктару Лаўрыновічу,

які ў 1812 г., калі французскае войска наплыло ў Літву і страшныя знішчэнні ды спусташэнні ў вялікім маштабе чыніла, будучы тут прыёрам, і на хвіліну не хацеў Шумска пакінуць, ратаваў, што мог і як удавалася, выцерпеўшы нямала знявагаў, здзекаў і неаднойчы нават фізічнага ўздзеяння. Пасля сканчэння пераходаў непрыяцельскіх войскаў а. Лаўрыновіч стараўся прывесці кляштар да зноснага існавання, для касцёла раздабыў самыя патрэбныя, хоць і сціплыя прадметы; пастараўся пра 
дапамогу сялянам, здабываючы для іх ежу і самае неабходнае; сякое-такое ўратаванне кляшторных і фальваркавых пабудоваў сталася толькі дзякуючы ягонай нястомнай энергіi ды руплівасці [Wołyniak 1917: 215-216].

Звернем яшчэ ўвагу на інфармацыю Валыняка, што ў Шумскім касцёле была колісь памятная дошка, якая сведчыла пра пахаванага тут суддзю Ашмянскага павета Казіміра Барэйку-Ходзьку (1739-1804) [Wołyniak 1917: 214], крэўнага (брата?) бацькі Яна Ходзькі (1777-1851). А г. зн. Ігнацы Ходзька (1794-1861), пэўна ж, ведаючы гісторыю недалёкага Шумскага кляштара, невыпадкова даў герою Успамінаў квестаpa прозвішча “Лаўрыновіч”.

Маем надзею, што некалі мы будзем ведаць значна больш і пра жыццё, і спадзяёмся - пра творчасць К. Марашэўскага.

\section{Бібліяграфія}

Bryl' Anton Francǐšak. 2018. Zvestkì pra Kaâtana Marašèǔskaga, Mìhala Câcerskaga ì İgnacyâ Ûrèviča ǔ dakumentah daminìkanskaga ordèna. "Rodnae slova” № 4: 3-4 [Брыль Антон Францішак. 2018. Звесткі пра Каятана Марашэускага, Міхала Цяцерскага і Ігнацыя Юрэвіча ў дакументах дамініканскага ордэна. "Роднае слова" № 4: 3-4].

Chodźko Dominik. 1856. Agłona: Kościół i klasztor oo. dominikanów. "Pamiętnik ReligijnoMoralny" № 8: 163.

Fibek Jan. Zabiały (Валынцы) - p. w. Św. Jerzego [online] https://www.radzima.org/be/ object_comm/7409.html [дата доступу: 13.07.2021].

Garèckì Maksìm, Dzâržynskì Uladzìslaǔ, Karavaj Pavel. 1926. Vypìsy z belaruskae litaratury, č. Ì: 1. Vusnaâ narodnâ̂ tvorčas'c'; 2. Staradaǔnae pìs'menstva. MaskvaLenìngrad [Гарэцкі Максім, Дзяржынскі Уладзіслаў, Каравай Павел. 1926. Выпісы з беларускае літаратуры, ч. I: 1. Вусная народная творчасьць; 2. Старадаўнае пісьменства. Масква-Ленінград].

Garèckì Maksìm. 1922. Hrystamatyâ belaruskae litèratury. XI vek - 1905 god. Vìl'nâ [Гарэцкі Максім. 1922. Хрыстаматыя беларускае літэратуры. ХІ век - 1905 год. Вільня].

Garèckì Maksìm. 1926. Gìstoryâ belaruskae lìtèratury, vydan'ne čac'vertae, peraroblenae. Mensk [Гарэцкі Максім. 1926. Гісторыя беларускае літэратуры, выданьне чацьвертае, пераробленае. Менск].

Karskìj Efimìj. 1912. Bělorusy, t. 2: Âzyk" bělorusskago plemeni, kn. 3: Očerki sintaksisa bělorusskago narečîa. Dopolneniâ i popravki. Varšava [Карскій Ефимій. 1912. Бълорусы, т. 2: Языкъ бплорусскаго племени, кн. 3: Очерки синтаксиса бплорусскаго наречія. Дополненія и поправки. Варшава].

Karskìj Efimìj. 1921. Bělorusy, t. III: Očerki slovesnosti běloruskago plemeni, č. 2: Staraâ zapadno-russkâ̂ pis'mennost'. Petrograd. [Карскій Ефимій. 1921. Бплорусы, т. III: Очерки словесности бплорускаго племени, ч. 2: Старая западно-русская письменность. Петроградъ].

Kolas Georgì. 1988. “Čy garast, spodaru?” “LìM” № 1 [Колас Георгі. 1988. “Чы гараст, сподару?” “ЛiМ” № 1].

Lietuvos mokslų akademijos Vrublevskių biblioteka (LMAVB), f. 18, b. 201, 1. 1-96r. 
Mal'dzìs Adam. 1974. Vakol Parnasa Zabel'skaj kalegìi. U: Mal'dzìs Adam. Taâmnìcy staražytnyh shoviščaǔ. Mìnsk: Mastackaâ lìtaratura [Мальдзіс Адам. 1974. Вакол Парнаса Забельскай калегіi. У: Мальдзіс Адам. Таямніцы старажытных сховішчаў. Мінск: Мастацкая літаратура.

Mal'dzìs Adam. 1996. Zabel'skì damìnikanskì kalegìum. U: Èncyklapedyâ gìstoryì Belarusì ú 6 tamah, t. 3. Mìnsk: Belaruskaâ èncyklapedyâ [Мальдзіс Адам. 1996. Забельскі дамініканскі калегіум. У: Энцыклапедыя гісторыі Беларусі ў 6 тамах, т. 3. Мінск: Беларуская энцыклапедыя].

Otčet o Vilenskoj publičnoj biblioteke i muzee za 1903 god. 1904. Vil'na [Omчem o Buленской публичной библиотеке и музее за 1903 год. 1904. Вильна].

Peretc" Vladimir". 1911. K" istorì pol'skago i russkago narodnago teatra. XVIII-XIX. "Izvestiâ Otdelenìâ russkago âzyka i slovesnosti Imperatorskoj Akademìi nauk" t. XVI, kn. 3: 248-319 [Перетцъ Владимиръ. 1911. Къ исторіи польскаго и русскаго народнаго театра. XVIII-XIX. “Известія Отделенія русскаго языка и словесности Императорской Академіи наук” т. XVI, кн. 3: 248-319].

Samborska-Kukuć Dorota. 2003. Wspomnienia o Zaborzu: Z historii teatrów dworskich na Kresach. "Pamiętnik Teatralny": 3-4.

Sołoduch Adam. 1923. Bibliografia: Maksim Harecki. Chrystamatyja Biełaruskaje Litaratury XI wiek - 1905 hod, Wilenskaje Biełaruskaje Wydawiectwa B. Kleckina, Wilnia 1922, str. 264 z ilustracjami. "Przegląd Wileński” nr 7.

Syčevskaâ Antonina. 1909. K" voprosu o Mol'erě v" pol'skoj dramatičeskoj literaturě XVIII st. "Russkìj filologičeskìj věstnik"” № 3 i 4 (т. LXII): 75-109 [Сычевская Антонина. 1909. Къ вопросу о Мольерп въ польской драматической литераmурп XVIII cm. “Русскій филологическій въстникъ” № 3 і 4 (т. LXII): 75-109].

Titius Julian. 1840-1841. Rys historyczny przedstawień teatralnych, mianowicie $w$ języku polskim, na Litwie. "Wizerunki i Roztrząsania Naukowe” t. 16: 179-182; t. 17:140145; t. 18: 97-139; t. 19: 85-93; t. 20: 85-96; t. 21: 110-130.

Usìkaǔ Âkub. 1964. Belaruskaâ kamedyâ: Lâ vytokaǔ žanru. Mìnsk: Vyšèjšaâ škola [Усікаy̆ Якуб. 1964. Беларуская камедыя: Ля вытокаў жанру. Мінск: Вышэйшая школа].

Wołyniak [Jan Marek Giżycki]. 1917. Wiadomości o dominikanach prowincyi litewskiej, cz. 1. Kraków.

Zânûk Raìsa.2012. Navučal'nyâ ǔstanovy pry Zabel'skìm damìnikanskìm klâštary (17161857 gg.). U: Vìcebskiâ staražytnascì: Matèryâly navukovaj kanferèncyì, prysvečanaj 90-goddzû sa dnâ naradžènnâ L.V. Alâkseeva. Vìcebsk, 28-29 kastryčnìka 2010 g. Mìnsk: Medysont [Зянюк Раіса. 2012. Навучальныя ўстановы пры Забельскім дамініканскім кляштары (1716-1857 г2.). У: Віцебскія старажытнасці: Матэрыялы навуковай канферэнцыі, прысвечанай 90-годдзю са дня нараджэння Л.В. Аляксеева. Віцебск, 28-29 кастрычніка 2010 г. Мінск: Медысонт].

ABSTRACT: The article examines the history of the Zabelsky manuscript collection, the problems of reading one of its texts - the famous Comedy, authored by Kayatan Marashevsky. The question is: did the Zabelsky Dominican Monastery have a college - an educational institution for the children of the wealthy nobility - and a theatre? In our opinion, in Walyncy there was a scriptorium - a kind of center for the preparation and rewriting of "exercises" for the training of clerics of the Dominican Order. Carefully analyzing the Zabel manuscript of 1787 , we came to the conclusion that it can be neither an autograph of K. Marashevsky nor an autograph of M. Tetersky. Another question that will have to be answered by 
literary historians: Are Liberty in Captivity and Comedy are K. Marashevsky's own works or texts that he prepared (collected, composed, reworked, etc.) for classes with students in lectures on poetry or rhetoric?

KEY WORDS: Walyncy, Zabely, Dominicans, manuscript, comedy, attribution, textology, Kayatan Marasheŭvski.

STRESZCZENIE: Artykuł omawia historię zabialskiego zbioru rękopisów, problemy z odczytaniem jednego z jego tekstów - słynnej Komedii autorstwa Kajetana Moraszewskiego. Stawiane są pytania: czy klasztor Dominikanów Zabielskich miał kolegium - instytucję edukacyjną dla dzieci zamożnej szlachty - i teatr? Naszym zdaniem w Wołyńcach znajdowało się skryptorium - rodzaj centrum przygotowania i przepisywania „ćwiczeń” do szkolenia duchownych Zakonu Dominikanów. Uważnie analizując zabialski rękopis z 1787 r. doszliśmy do wniosku, że nie może to być ani autograf K. Moraszewskiego, ani autograf M. Ciecierskiego. Kolejne pytanie, na które historycy literatury będą musieli odpowiedzieć sobie: czy Wolność w niewoli i Komedii to utwory K. Moraszewskiego lub teksty, które on przygotował (zebrał, komponował, przerabiał itp.) na zajęcia ze studentami z poetyki lub retoryki?

SŁOWA KLUCZOWE: Wołyncy, Zabiały, Dominikanie, rękopis, komedia, atrybucja, tekstologia, Kajetan Moraszweski.

РЭЗЮМЭ: У артыкуле разглядаецца гісторыя забельскага рукапіснага зборніка, праблемы расчытання аднаго з ягоных тэкстаў - славутае Камедыі, аўтарам якое лічыцца Каятан Марашэўскі. Ставіцца пытанне: ці існаваў пры Забельскім дамініканскім кляштары калегіум - навучальная ўстанова для дзяцей заможнае шляхты - і тэатар? На нашую думку, у Валынцах "дзейнічаў" скрыпторый - своеасаблівы асяродак па падрыхтоўцы і перапісванні “практыкаванняў” дзеля навучання клерыкаў дамініканскага ордэна. Уважліва прааналізаваўшы забельскі рукапіс 1787 г., мы прыйшлі да высновы, што ён не можа з'яўляцца ні аўтографам К. Марашэўскага, ні аўтографам М. Цяцерскага. Чарговае пытанне, на якое неабходна будзе адказаць гісторыкам літаратуры: Вольнасць у няволі і Камедыя - гэта ўласныя творы К. Марашэўскага ці тэксты, якія ён падрыхтаваў (сабраў, склаў, перапрацаваў і інш.) дзеля заняткаў са студэнтамі на лекцыях паэтыкі альбо рыторыкі?

ключАВыя словы: Валынцы, Забелы, дамініканцы, рукапіс, камедыя, атрыбуцыя, тэксталогія Каятан Марашэўскі.

Data przesłania artykułu: 1.11.2021

Data akceptacji artykułu: 25.11.2021

\section{ABOUT THE AUTHOR / O AUTORZE}

Mikałaj Chaustowicz / Мікола Хаўстовіч - Polska, Uniwersytet Warszawski, Katedra Białorutenistyki; dr hab., prof.; specjalność naukowa: literaturoznawstwo białoruskie; zainteresowania naukowe: literatura białoruska w XIX wieku, polskobiałoruskie związki literackie.

Adres: Katedra Białorutenistyki Uniwersytetu Warszawskiego, ul. Szturmowa 4, 02-678 Warszawa, Polska. 


\section{Wybrane publikacje (2020-2021):}

1. Хаўстовіч Мікола. 2020. Даследаванні і матэрыялы: Літаратура Беларусі ХІХ стагоддзя, том шосты: Беларускія тэксты Паўстання 1863 года. Warszawa: Katedra Białorutenistyki Uniwersytetu Warszawskiego.

2. Хаўстовіч Мікола. 2020. Літаграфаваная "Гутарка старога дзеда на Беларусі" ўкантэксце рукапісаў і выданняў твора. У: В.Ю. Боровко, Е.В. Крикливец (рэд.). Аксиологический диапазон художественной литературы: Сборник научных статей (с. 249-253). Витебск: Выдавецтва ВдУ.

3. Хаўстовіч Мікола. 2021. Даследаванні і матэрыялы: Літаратура Беларусі ХІХ пачатку XX стагоддзя, том сёмы. Warszawa: Katedra Białorutenistyki Uniwersytetu Warszawskiego.

4. Хаўстовіч Мікола. 2021. Беларускія вершы Адама М-скага: тэксты і кантэксты. „Acta Polono-Ruthenica” XXVI/2: 75-88.

5. Хаўстовіч Мікола. 2021. Праблемы атрыбуцы вершаванага драматургічнага абразка ATWIECZEREK. „Studia Białorutenistyczne” 15: 157-173. 

